\title{
INVESTIGATING CODE-MIXING AS PERSUASIVE STRATEGIES IN ADVERTISING: A STUDY OF CODE-MIXING IN INDONESIAN COMMERCIAL CONTEXT
}

\author{
Rosmiaty \\ rosmiatypammu@gmail.com \\ Politeknik Sandi Karsa \\ Ratnawaty \\ $\frac{\text { ratnawaty.aba@umi.ac.id }}{\text { Akademi Bahasa Asing }}$ \\ Asriani Muhri \\ asrianimuhri@gmail.com \\ Akademi Bahasa Asing
}

\begin{abstract}
This study deals with the phenomena of code-mixing with a specific focus on commercial advertising specifically in Indonesian commercial context. It analyzes the use of these techniques in order to produce a persuasive effect in Indonesian today. The objective of this study to investigate the forms of code mixing used in Commercial Advertisement and to shed light on the factors of using code mixing in Commercial Advertisement. The study employs a qualitative descriptive approach by describing about forms and factors of using code mixing in Commercial Advertisement. The research findings revealed six forms of code mixing utilized in Indonesian Commercial Advertisement today. Those are words, phrase, hybrid, repetition, idioms, and clause. The study further showed the factors of using code mixing in Commercial Advertisement. Those were interjection (Inserting sentence fillers or sentence connectors), quoting somebody else, talking about a particular topic, expressing group identity, being emphatic about something and repetition used for clarification.
\end{abstract}

Keywords: Code-mixing, Indonesian Commercial, Advertisment Strategy

\section{INTRODUCTION}

Language is communication tool for every people. Languages provide a variety of ways of saying the same thing - addressing and greeting others, describing things, paying compliments (Janet Holmes, 2013:3). People used language to communicate and pass on information. As a tool of communication, language is an essential part in human life. Language plays an important role as the main subject that determines whether the communication it self can be done successfully or not. According to Tira Nur Fitria (2014:1-2) research that said that language has an important part in human life and has several usages for human as a mean of communication and interaction in community life. It means that language is a key of communication in connecting one person with the other person. Without a good language we would be unable to express our feeling, emotion, ideas, opinion, information and we would not be able to share our knowledge.

Sometimes people want to make a conversation only with certain people or their community. They may try a different language to avoid the other people or other community 
interfering their communication. Besides in the communication, the relation between language and society can not be separated. The study about the relation of language and society is called sociolinguistic. Ronald Wardhaugh and Janet M. Fuller (2015:1) said sociolinguistics is the study of our everyday lives - how language works in our casual conversations and the media we are exposed to, and the presence of societal norms, policies, and laws which address language. So, sociolinguistics learns, discusses and focuses on how a language used in society.

According to definition of sociolinguistics, the sociolinguists study the relationship between language and society. Sociolinguists are interested in how we speak differently in varying social contexts, and how we may also use specific functions of language to convey social meaning or aspects of our identity. Sociolinguistics teaches us about real-life attitudes and social situations (School of English, 2015). As language is seen as communication tool and can not be separated with society, people nowdays mostly use English language that has been taught around the world and easy to found it in the convertation. In short, English language is seen as a language that has complex relation with this globalization era which has their own control with the people who use it.

Almost everyone speaks based on where they came from and their environment. It is happens in every gender, age, status and society. When people are in conversation, they use the language that they have. Hundred of million people all over the world routinely use two or more languages in their daily lives. At this time there are so many people who master more than one language that we know as bilingualism. Bilingualism is the phenomenon of people having more than one languages. In bilingual or multilingual community, speaker tends to mix from one code or language to the others. When people use and mix two or more codes and languages is commonly called as code mixing (Safitri, Harida, Hamka, 2017:165).

Code mixing is the mixing of two or more languages varieties in speech. The speakers use code mixing to serve their communicative purpose and express their mood also. In Steemit site, Wiraonly (2017) said that the ability of speaking in two languages makes code mixing occurs when bilingual society mixed word, phrase and clause together from one language to another in one sentence.

Hundred of million people all over the world routinely use two or more languages in their daily lives (Arham \& Hudriati, 2018). The fact that people can use more than one languages encourages them to mix code whenever they speak. Nowdays, code mixing has become a world wide phenomenon, which is very interesting to study and analyze. Code mixing usually happens because of special purposes such as for an identity and solidarity. We can find code mixing in verbal communication and non verbal communication. Code mixing in non verbal communication can be found in texts such as: newspaper, magazine, novel, article, script, and movie script. Beside that, one of the example of code mixing in verbal communication is commercial advertisement. In Wikipedia site, commercial advertisement or television commercial is a span of television programming produced and paid for by an organization. The commercial advertisement conveys a message, aimed to market a product or service.

This study takes commercial advertisement as the object used because nowadays the use of english in commercial advertisement is very common. Stemming from those reasons the authors decides to find out the forms of code mixing used in Indonesian Commercial Advertisement and the factors of using code mixing in Indonesian commercial context. The authors hope that it can help people to understand the forms and the factors of using code mixing in commercial advertisement.

\section{Literature Review Sociolinguistics}

Sociolinguistic is a field of macro linguistics in linguistic study. Sociolinguistics is the study of language in relation to society. Sociolinguistics is concerned with the relationship between language and the context in which it is used (Janet Holmes, 2013:1). According to Wardhaugh (2006:13), sociolinguistics is concerned with investigating the relationship between language and society with the goal being a better understanding of the structure of language and of how languages function in communication: the equivalent goal in the sociology of language is trying to discover how social structure can better understood through the study of language. 
In the other words, in sociolinguistics we study language and society in order to find out as much as we can about what kind of thing language is, and in the sociology of language we reverse the direction of our interest.

Further on Janet Holmes (2013:1) defines that sociolinguists study the relationship between language and society. They are interested in explaining why we speak differently in different social contexts, and they are concerned with identifying the social functions of language and the ways it is used to convey social meaning. The sociolinguistics is concerned with the relationship between language and the context in which it is used.

It means sociolinguistics is not a study of facts but the study of ideas about how member of a particular society may influence the terms with our language use.

\section{Definition of Code Mixing}

Code or variety of language is the choice of words. By the existence of the language varieties, some people need to choose the code or interaction strategy correctly to be used at random context (Wibowo, Yuniasih, Nelfianti, 2017). One of the effect of using two or more languages or bilingualism phenomenon is code mixing. The definitions about code mixing is when the conversant mix two or more languages in a speech or in a discourse without any requirement, the relaxed of the speaker or his/her habit get involved in that situation (Safitri, Harida, Hamka, 2017).

The other definition of code mixing is the change of one language to another within the same utterance or the same oral or written text. Amelia, Suarnajaya and Sintya Dewi (2018) state, Code mixing is a process of mixing two languages or more which occur without changing the topic. And in principle code mixing is the mixing from one language into the structure of other language such as word, phrase, clause, and even sentence from a cooperative activity where the participants in order to infer what is intended.

The phenomenon of code mixing happens not only in speaking or writing (formal situation), but code mixing also used in other interaction in daily life, such as in the movie or film, song, novel, magazine, radio, news, commercial advertisement, and social media networking too such as intagram, twitter, facebook, and even in the group chat of social media.

\section{Types of Code Mixing}

According to Suwito (1983:76) in Isna Navi'a Dini (2017) research, code mixing is divided into two types :

1. Inner code mixing, in which happens because elements insertion from original language with all its variation It occurs if the speakers insert the elements of their second language into their first language, the elements of first language into their second language, or elements of varieties and style into their utterance.

2. Outer code mixing, in which occurs because of elements insertion stemming from foreign language in an utterance when they mostly speak with whether their first language or second language.

It means that the first language of the speaker in this case, national language is inserted with his or her own language (original language) or inserted with a foreign language from the speaker background.

\section{Forms of Code Mixing}

The research of Adindah Novihartina (2018) differentiates the kind of code mixing in the form of words, phrase, hybrid, repetition word, idioms and clauses base on Suwinto (1985:78).

1. Code mixing in the form of word

Word is the smallest unit of language consists of a morpheme or more than a morpheme.

Example : hadirilah party ku malam ini (Come to my party tonight)

2. Code mixing in the form of phrase

Phrase is grammatical analysis to refer to a single element of structure typically containing more than one words, and lacking the subject and predicate structure typical of clauses. Phrase insertion here a sequence of words which is semantically and often syntactically restricted, and functioning as a single unit.

Example : Rumah Sakit ini membutuhkan fresh graduate yang berkompeten. 


\section{METHOD}

This study is follows the descriptive qualitative approach since the study emphasizes on a complete description of the types, and the reasons of Code Mixing occurrence in Commercial Advertisement specifically in Indonesian context. As a qualitative research, all the data in this research were in the form of words as Bogdan and Taylor state in Hani Herennisa (2018:36) that qualitative method is a research procedure resulting in descriptive data, whether in written or oral form, from the investigated people and behavior. In other words, qualitative research is a kind of research that cannot be counted. The authors used qualitative descriptive, because the authors described about forms and reasons of code mixing in commercial advertisement. The focus of this study is the use of code mixing which is used in ten Indonesian commercial advertisement of food and drink advertisement. Since the commercial advertisement can be found online, this study visited some channel from YouTube accessed from- www.youtube.com for collecting data and sample selection.

The data was analyzed by following several steps, they are; (1) Identifying the sentences which is found in the advertisement, (2) Identifying and classifying the data based on the forms of code mixing and the factors of using code mixing, and (3) making a conclusion based on the analysis.

\section{FINDINGS AND DISCUSSION}

The authors classify the data in this research based on the forms of code mixing and the factors of code mixing used in commercial advertisement. The data that found is qualitative data. In this research, the data are analyzed based on the data classification. The data of code mixings which are analyzed by the authors are collected from youtube. In youtube, the authors found code mixings in various forms and found many factors of using code mixing in commercial advertisement. There are code mixing in the form of word, phrase, hybrid, repetition, idiom, and clause. And there are factors of using code mixing such as interjection (Inserting sentence fillers or sentence connectors), quoting somebody else, talking about a particular topic, expressing group identity, being emphatic about something and repetition used for clarification.

After the process of classifying the data, the code mixings that are found by the authors in YouTube are 10 utterances. The classifications of code mixing in the form of word are 6 data, code mixing in the form of phrase are 5 data, code mixing in the form of hybrid are 4 data, code mixing in the form of repetition word is 1 data, code mixing in the form of idiom is 1 data, and code mixing in the form of clause are 3 data.

Table 1. Code Mixing in Form of Data

\begin{tabular}{|c|c|c|c|}
\hline No. & $\begin{array}{l}\text { Commersial } \\
\text { Advertisment }\end{array}$ & Form & Utterance \\
\hline 1. & Chitato & Idiom & $\begin{array}{l}\text { Makasih untuk semua yang udah } \\
\text { kita lewati. } \\
\text { Dan teruslah jadi inspirasi kami } \\
\text { berinovasi. } \\
\text { Menciptakan rasa dan } \\
\text { pengalaman yang akan selalu } \\
\text { dinanti. } \\
\text { Chitato, live is never flat. }\end{array}$ \\
\hline 2. & Tango & $\begin{array}{l}\text { - Word } \\
\text { - Hybrid }\end{array}$ & $\begin{array}{l}\text { So cuma Tango yang berasa } \\
\text { manisnya. } \\
\text { So Cuma Tango yang dapat } \\
\text { crispy-nya. } \\
\text { So cuma Tango yang berlapis } \\
\text { lezatnya } \\
\text { Makanya tango biar enak } \\
\text { So makanya tango } \\
\text { Biar enak }\end{array}$ \\
\hline
\end{tabular}




\begin{tabular}{|c|c|c|c|}
\hline 73 & \multicolumn{3}{|c|}{$\begin{array}{l}\text { ELT Worldwide Vol. } 7 \text { No. } 1 \text { (2020) } \\
\text { Rosmiaty, Ratnawati, Asriani: Investigating Code-Mi ... }\end{array}$} \\
\hline 3. & $\begin{array}{l}\text { Tim Tam Wafer } \\
\text { Smooth and Crunchy }\end{array}$ & $\begin{array}{ll}\text { - } & \text { Word } \\
\text { - } & \text { Clause }\end{array}$ & $\begin{array}{l}\text { A : Pev, cabut yuk! } \\
\text { B : Bentar yah. cobain nih! } \\
\text { A : OMG! tim tam wafer baru! } \\
\text { A : Baru! Tim Tam Wafer } \\
\text { Smooth and Crunchy. } \\
\text { Finger size crunchy wafer } \\
\text { dengan krim yang smooth } \\
\text { berlapis coklat lezat. } \\
\text { Bikin kamu dan sahabat lupa } \\
\text { waktu. } \\
\text { Tim Tam Wafer Smooth and } \\
\text { Crunchy. } \\
\text { Lebihhhh dari sekedar wafer. }\end{array}$ \\
\hline 4. & Beng-beng Share It & $\begin{array}{l}\text { - Word } \\
\text { - } \quad \text { Phrase }\end{array}$ & $\begin{array}{l}\text { Nikmatnya beng-beng mana } \\
\text { tahan. Lembutnya caramel, } \\
\text { renyahnya crispy rice, dan } \\
\text { wafer berbalut coklat asli yang } \\
\text { bikin meleleh. } \\
\text { Bagi dong... } \\
\text { Nih yang baru beng-beng Share } \\
\text { it. } \\
\text { Isinya banyak bisa buat rame- } \\
\text { rame. }\end{array}$ \\
\hline 5. & Better & $\begin{array}{l}\text { - Hybrid } \\
\text { - Word }\end{array}$ & $\begin{array}{l}\text { A : Nih surat cinta. Eh buat dia. } \\
\text { B : Galau php! } \\
\text { Better-in aja pake edisi anti } \\
\text { galau. } \\
\text { Diphpin? kan masih ada yang } \\
\text { lain. } \\
\text { Biskuit tebal cokelat yang } \\
\text { crunchy. } \\
\text { Cokelatnya enak. Galaunya } \\
\text { ilang. Eh ada edisi lain. Buat } \\
\text { yang galau eksis, galau tugas dan } \\
\text { galau lainnya. } \\
\text { Galau? Dibetter-in aja. }\end{array}$ \\
\hline 6. & Sprite & Phrase & $\begin{array}{l}\text { Hey Guys! } \\
\text { Apa iya, ucapan dan kenyataan } \\
\text { itu pasti sama? } \\
\text { Katanya, es batu itu ngademin? } \\
\text { Lemon lime itu...Bukannya } \\
\text { jeruk? } \\
\text { Dan air putih... Emang } \\
\text { warnanya putih? } \\
\text { Hah? Bingung? } \\
\text { Makanya, pilih yang jernih- } \\
\text { jernih aja, Kayak sprite. } \\
\text { Dengan lemon lime dan } \\
\text { gelembung yang nyegerin. } \\
\text { Sprite Nyatanya Nyegerin. No } \\
\text { Bokis. }\end{array}$ \\
\hline
\end{tabular}


Rosmiaty, Ratnawati, Asriani: Investigating Code-Mi ...

\begin{tabular}{|c|c|c|c|}
\hline 7. & Floridina & $\begin{array}{ll}\text { - } & \text { Phrase } \\
\text { - } & \text { Hybrid } \\
\text { - } & \text { Clause }\end{array}$ & $\begin{array}{l}\text { Bulirrrrr } \\
\text { Hey bulir? Nih floridina. } \\
\text { Bikin hari mu lebih seru. } \\
\text { Karena floridina dari florida } \\
\text { orange. } \\
\text { Fresh-nya gak abis-abis } \\
\text { Bulirnya utuh. It pop. } \\
\text { Where all the fun begins } \\
\text { Butuh bulir? Butuh floridina. } \\
\text { Bulirnya utuh. }\end{array}$ \\
\hline 8. & Ichi Ocha & $\begin{array}{ll}\text { - } & \text { Word } \\
\text { - } & \text { Phrase }\end{array}$ & $\begin{array}{l}\text { Demi likes, followers, demi } \\
\text { konten. } \\
\text { Gue kejebak jadi Instagram } \\
\text { boyfriend. } \\
\text { Emang susah bodi hati lo, gerah! } \\
\text { Ichi ocha langsung siap, gerah! } \\
\text { Segeran bodi dan hati lo. } \\
\text { Ichi ocha. }\end{array}$ \\
\hline 9. & Ichitan Thai Coffee & $\begin{array}{l}\text { - Clause } \\
\text { - Repetition } \\
\text { - Phrase }\end{array}$ & $\begin{array}{l}\text { A : Panas banget nih. Beli } \\
\text { minum yuk. } \\
\text { B : Sawadikap. } \\
\text { A : Hello, Is this thai milk tea? } \\
\text { B : No no. Thai coffe. } \\
\text { A : Oh, oke oke. Two two. } \\
\text { Wah nih kopi nih beda yah. } \\
\text { Heem enak ya, enak banget. } \\
\text { Coba ada di Indonesia yah. } \\
\text { Tenang aja ada ichitan thai milk } \\
\text { coffee. } \\
\text { Beneran kopi Thailand. } \\
\text { Mau cobain dong. }\end{array}$ \\
\hline 10. & Goodmood Water & $\begin{array}{ll}\text { - } & \text { Word } \\
\text { - } & \text { Hybrid }\end{array}$ & $\begin{array}{l}\text { Dalam hidup ada beragam } \\
\text { pilihan. } \\
\text { Pilihan yang salah, bikin kamu } \\
\text { jadi badmood. } \\
\text { Dan kalau badmood banyak hal } \\
\text { bisa jadi kacau. } \\
\text { Pilihan yang benar, bikin kamu } \\
\text { jadi goodmood. } \\
\text { Dan kalau goodmood itu bisa } \\
\text { membawamu ke hal-hal baik. } \\
\text { Jadi mood apa yang kamu pilih } \\
\text { hari ini? } \\
\text { Ubah mood-mu, ubah duniamu. }\end{array}$ \\
\hline
\end{tabular}

\section{Discussion}

Based on on the ten video of commercial advertisements, there were six commercial advertisement that used code mixing in the form of word. There were Tango, Tim Tam Wafer Smooth and Crunchy, Beng-beng Share it, Better, Ichi Ocha, and Goodmood water. One analysis is shown below:

\section{Tango}

So cuma Tango yang berasa manisnya.

So Cuma Tango yang dapat crispy-nya.

So cuma Tango yang berlapis lezatnya

Makanya tango biar enak 
So makanya tango

Biar enak.

Based on utterance above, the code mixing in the form of word is the word so. The word so here has a meaning "jadi" in Indonesian language.

\section{CONCLUSION}

The conclusions in this study is the first conclusion which deals with the forms of code mixing used in Indonesian commercial advertisement. The second conclusion deals with the factors of code mixing used in commercial advertisement.

The analysis showed that the forms of code mixing used in commercial advertisement were the form of word, the form of phrase, the form of hybrid, the form of repetition, the form of idiom and the form of clause. The research further identified the factors of using code mixing in commercial advertisement they were: interjection (inserting sentence fillers or sentence connectors), quoting somebody else, talking about a particular topic, expressing group identity, being emphatic about something and repetition used for clarification.

The result of the research can be used as a reference in studying linguistics, especially about sociolinguistics and more specific into code mixing which employed in commercial advertisement. It had better if the next authors also takes a discussion in other media. The authors who can also develop this research is not only limited by the forms and the factors of using code mixing, but also it can be added by code mixing usage purposes, analyze with the structure and culture more detail.

Furthermore, the result of this study may be helpful for the reader to shed some light that English can also be learned in commercial advertisement context. The code mixing itself not only can be found orally form daily conversation, but also it can be found in commercial advertisement. By reading this study, the authors hope that the readers can develop the language by using more than one language to face the modern life style.

\section{REFERENCES}

Amelia, Mashita K.S., I. W. Suarnajaya, K. Sintya Dewi. 2018. An Analysis of Code Mixing Used in Instagram by The Students of English Language Education. E-Journal Undiksha.

Arham, M., Akrab, A.H. (2018). Delving into Delving into Content Lecturers' Teaching Capability in Content Language Integrated Learning (CLIL) at an Indonesian University, Asian ESP Journal, Vol. 14 No. 7.2 (2018).

Creswell, Jhon W. (2003), Research Design: Qualitative, Quantitative, and Mixed Methods Approaches, New delhi: Sac Publications, inc.

Fahrurrozy. 2015. Analysis of Code Mixing in Commercial Advertisement. Repository UIN Jakarta.

Fitria, Tira Nur. 2014. Sociolinguistic "Code Switching and Code Mixing". Academia Edu.

Herennisa, Hani. 2018. Code Mixing in Students' Whatsapp (Wa) Chat At Eight Semester of English Study Program at State Islamic of University Raden Intan Lampung. Repository Raden Intan.

Hoffman, C. 1991. An Introduction to Bilingualism. London : Longman. 
Holmes, Janet. 2013. An Introduction to Sociolinguistics. Fourth Edition. Third Avenue, New York : Routledge.

Novahartina, Adindah. 2018. The Use of Code Mixing in Twitter. Submitted to the Academy of Foreign Language Muslim University of Indonesia

Safitri, Laila, E.S. Harida, Hamka. 2017. The Analysis of Code Mixing on Students' Facebook: A Study on Facebook Status and Comments of The Sixth Semester Students TBI IAIN Padangsidimpuan. Volume 1. English Language Teacher and Research.

Saputra, Medi Heri. 2018. An Analysis of Code-Switching Used in Honda Advertisement in Indonesia. IOSR Journal of Humanities and Social Science (IOSR-JHSS).

School of English. 2015. What does Sociolinguistics study? http://all-aboutlinguistics.group.shef.ac.uk/branches-of-linguistics/sociolinguistics/what does-sociolinguistics-study/

Teresita D. Tajolosa. 2013. Motivations for Code-switching in Advertising and the Construction of Consumers' Multiple Identities: The Case of Philippine TV Commercials. Philippine ESL Journal,.Vol. 11, July 2013

Wardraugh, Ronald. 2006. An Introduction to Sociolinguistic. Fifth Edition. Oxford: Blackwell Publishing 